\title{
Factors that influence the membrane area of a multistage microfiltration process required to produce a micellar casein concentrate ${ }^{1}$
}

\author{
Emily E. Hurt and David M. Barbano ${ }^{2}$ \\ Northeast Dairy Foods Research Center, Department of Food Science, Cornell University, Ithaca, NY 14853
}

\section{ABSTRACT}

The objective of the work reported in this paper was to develop a theoretical model to determine the effect of type of microfiltration (MF)-process feed, number of stages, and flux on the minimization of the MF membrane area required to produce a $95 \%$ serum protein-reduced micellar casein concentrate. The MF feed, number of stages, and flux were all factors that had an effect on the MF membrane area and should be taken into consideration when designing a MF system to produce a $95 \%$ serum protein-reduced micellar casein concentrate. Feeding the MF process with a diluted ultrafiltration retentate (DUR) diluted to the protein concentration of skim milk, as opposed to skim milk, reduced the required membrane area by $36 \%$ for a 5 -stage process. When DUR was the MF feed, feed protein concentration, which depended on the number of MF stages, was optimized. The DUR protein concentration that minimized the required MF membrane area was $2.47,3.85,4.77$, and $5.41 \%$ for a $2-, 3-$, $4-$, or 5 -stage MF process, respectively. For a 5-stage process, increasing the protein concentration of the feed from 3.2 to $5.4 \%$ decreased the required MF membrane area by $10 \%$. It was also found that as the number of stages increased from 2 to 5 , the required MF membrane area decreased by $39 \%$, when the MF feed was DUR at the optimal feed protein concentration. Finally, increasing the flux from 50 to $60 \mathrm{~kg} / \mathrm{m}^{2}$ per hour decreased the required MF membrane area by $17 \%$ when the MF feed was DUR at the optimal MF feed protein concentration. Overall, using DUR as a feed for MF could reduce the amount of MF membrane area required to make a $95 \%$ serum protein-reduced micellar casein concentrate.

Key words: microfiltration, membrane area, flux, micellar casein concentrate

\footnotetext{
Received September 20, 2014.

Accepted December 9, 2014.

${ }^{1}$ Use of names and names of ingredients and identification of specific models of equipment is for scientific clarity and does not constitute any endorsement of a product by the authors, Cornell University, or the Northeast Dairy Foods Research Center.

${ }^{2}$ Corresponding author: dmb37@cornell.edu
}

\section{INTRODUCTION}

\section{Microfiltration of Skim Milk}

Microfiltration (MF) can be used to remove serum protein (SP) and lactose from the micellar $\mathrm{CN}$ in skim milk (SM). The micellar $\mathrm{CN}$ is retained by the MF membranes and concentrated in the retentate, whereas a major portion of SP, lactose, NPN, and serum-phase minerals pass through the membrane into the permeate. Both ceramic (Fauquant et al., 1988; Zulewska et al., 2009; Adams and Barbano, 2013) and polymeric MF membranes (Lawrence et al., 2008; Beckman et al., 2010) have been used to MF SM. The type of membrane has been found to have an effect on the SP removal efficiency. Zulewska et al. (2009) compared 2 types of ceramic MF membranes to a polymeric spiral-wound membrane. Zulewska et al. (2009) found that the ceramic membranes in a 1-stage system operating at a concentration factor $(\mathbf{C F})$ of $3 \times$ removed 64 and $61 \%$ of the SP, which was close to the theoretical removal of 69\% (Hurt and Barbano, 2010); the percentage of SP removed by the polymeric membranes was significantly less at 39\%. Zulewska and Barbano (2014) reported that for a 3 -stage MF process running at a $\mathrm{CF}$ of $3 \times$, a total of $1,208 \mathrm{~m}^{2}$ of a ceramic $0.1-\mu \mathrm{m}$ graded permeability membranes would be required to remove $95 \%$ of the SP from 1 million kilograms of skim milk at flux of $92 \mathrm{~kg} / \mathrm{m}^{2}$ per hour, whereas $2,051 \mathrm{~m}^{2}$ would be required for the same process using a uniform transmembrane pressure system at a flux of $54 \mathrm{~kg} / \mathrm{m}^{2}$ per hour.

The retentate from MF is a micellar $\mathrm{CN}$ concentrate (MCC) that could be used in multiple applications, including formulation of shelf-stable nutritional beverages. For nutritional-beverage applications involving high-heat treatment, the large reduction in the heatlabile components in MCC (SP and lactose) may be critical. The sensory properties of fresh liquid MCC retentates could be superior to other dried CN ingredients (i.e., rennet $\mathrm{CN}$, sodium and calcium caseinates). The composition of MCC with respect to SP and lactose concentration as well as protein concentration will depend on the MF process and membrane equipment. The permeate from MF will consist mainly of SP and lactose. Further processing of the MF permeate by UF 
Table 1. Micellar casein concentrate (MCC) target composition (\% by weight) and percent reduction of lactose and serum protein compared with skim milk

\begin{tabular}{lccc}
\hline Item & Protein & Serum protein & Lactose \\
\hline Concentration in MCC (\% by weight) & 9.00 & 0.098 & 0.20 \\
Percent reduction (compared with skim milk) & - & 95 & 98.8 \\
\hline
\end{tabular}

to concentrate the SP would produce SP concentrates. These SP concentrates could be used in applications similar to whey protein concentrates and in new applications in protein fortification where their clarity relative to whey protein concentrates (Luck et al., 2013) would be an advantage.

\section{MF Process Design}

In designing a multistage MF process to produce an $\mathrm{MCC}$, the number of stages, retentate protein concentration, and the flux at which the system will operate at all have to be specified. These parameters could have an effect on the overall MF membrane area required and the cost of the system. A processor considering installing an MF system to produce MCC may already be using UF to produce milk protein concentrates (MPC). In this case, it will be possible to feed the MF-process-with-UF SM (MPC) as opposed to SM. Because the UF process will remove lactose, an MCC produced from UF SM would be expected to have a lower concentration of lactose compared with an MCC produced with SM using the same MF process.

For a MF process designed to produce an MCC, a main objective would be to produce an MCC meeting customer specifications while minimizing the cost of the system, including the cost of required diafiltration water. In the current work MF membrane area was used as a proxy for system cost, and the amount of MF permeate produced (and diafiltration water) was also calculated. To determine the relationship between the process design parameters and required MF membrane area, a theoretical MF model was developed where the effect of MF-process feed, number of stages, and flux on MF membrane area could be determined. The objective of the work reported in this paper was to develop a theoretical model to determine the effect of type of MF-process feed, number of stages, and flux on the minimization of the MF membrane area required to produce a $95 \%$ SP-reduced MCC.

\section{MATERIALS AND METHODS}

\section{Composition}

The goal of the theoretical MF process was to produce an MCC with a reduced concentration of SP and lactose. The MF process would also reduce the concentration of other serum-phase components of SM such as NPN and ash in the MCC, but the concentration of these components in the final MCC was not specified. The target MCC composition is shown in Table 1 . The target MCC protein concentration was $9 \%$ with at least $95 \%$ of the SP and $98.8 \%$ of the lactose removed. The target MCC composition was somewhat arbitrary, but input from retorted milk-based-beverage processors indicated that it was desirable to remove a large amount of the heat-labile SP, as well as to have a high final protein concentration. Additionally, a very low level of lactose in the MCC was desired so that the beverages produced using this protein ingredient could be labeled lactose free.

\section{Model Development}

A theoretical model was developed using Excel 2007 (Microsoft, Redmond, WA) to determine the composition and mass of the retentate and permeate produced from each stage of a MF process that could consist of 2 to 5 stages. The retentate from the final stage was the MCC. The model was based on previous work by Hurt and Barbano (2010). It was assumed that each MF stage was a continuous feed-and-bleed system (with the composition of the material in the recirculation loop equal to the composition of the retentate removed from that stage) with water dilution between stages. The composition used for the SM feeding the first MF stage is shown in Table 2. A mass of 150,000 kg of SM was used in the model as the initial MF feed.

The CF and diafiltration factor (DF) determined the mass and composition of the retentates and permeates produced as shown in Figure 1. The CF was the mass of MF feed for a stage divided by the mass of retentate produced in that stage. The DF determined how much water was added to the retentate from the previous stage to arrive at the feed for the current stage. The DF was the mass of MF feed from the current stage divided by the mass of retentate from the previous stage.

\section{Model Assumptions}

As in the research by Hurt and Barbano (2010), it was assumed that two-thirds of the ash in the SM was associated with the $\mathrm{CN}$ micelles and could not 
Table 2. Composition (\% by weight) of the microfiltration (MF) feed, skim milk (SM) or diluted UF retentate (DUR), and the starting milk protein concentrate (MPC)

\begin{tabular}{llll}
\hline & \multicolumn{3}{c}{ MF feed } \\
\cline { 2 - 3 } Item & SM & DUR & \\
\hline Protein & 3.20 & 3.20 & 12.00 \\
CN & 2.623 & 2.623 & 9.836 \\
Serum protein & 0.577 & 0.577 & 2.164 \\
Lactose & 4.85 & 1.164 & 4.365 \\
NPN & 0.190 & 0.046 & 0.171 \\
Ash & 0.729 & 0.544 & 2.04 \\
\hline
\end{tabular}

be removed by MF; this assumption was necessary to calculate the concentration of components in the serum phase of SM. Assumptions were also made regarding the transmission of components through the membrane. It was assumed that the removal factors for SP and lactose were one. A removal factor of one indicated that the component was not rejected by the membrane. The removal factor was equal to the concentration of the component in the permeate divided by the concentration of that component in the serum phase of the MF feed. The concentration of SP in the serum phase (\% by weight) was calculated using Equation 1. Additionally, it was assumed that the MF membranes retained all of the $\mathrm{CN}$ (the concentration of $\mathrm{CN}$ in the permeate was $0 \%$ ). The assumptions on the transmission characteristics of the MF membrane are a best-case scenario. However, previous research has found that $0.1-\mu \mathrm{m}$ ceramic membranes with $4-\mathrm{mm}$ channel diameters in a uniform transmembrane pressure system perform with near theoretical SP removal for a $3 \times$ process $(67 \%$ for 1 stage compared with a theoretical removal of $68 \%$; Hurt et al., 2010). The SP removal reported for ceramic membranes is higher than the reported SP removal for polymeric membranes (Beckman et al., 2010):

$$
[\mathrm{SP}]_{\text {serum phase }}=\frac{[\mathrm{SP}]_{\mathrm{feed}}}{1-\frac{[\mathrm{CN}]_{\mathrm{feed}}}{100}-\frac{2}{3} \frac{[\mathrm{Ash}]_{\mathrm{feed}}}{100}}
$$

\section{Factors that Could Affect the Required MF Membrane Area}

$\boldsymbol{U F}$ of $\boldsymbol{S M}$. The possibility of ultrafiltering SM before MF to remove lactose was included in the analysis. Skim milk that had been UF (with or without diafiltration) would be an MPC; in this work it was assumed

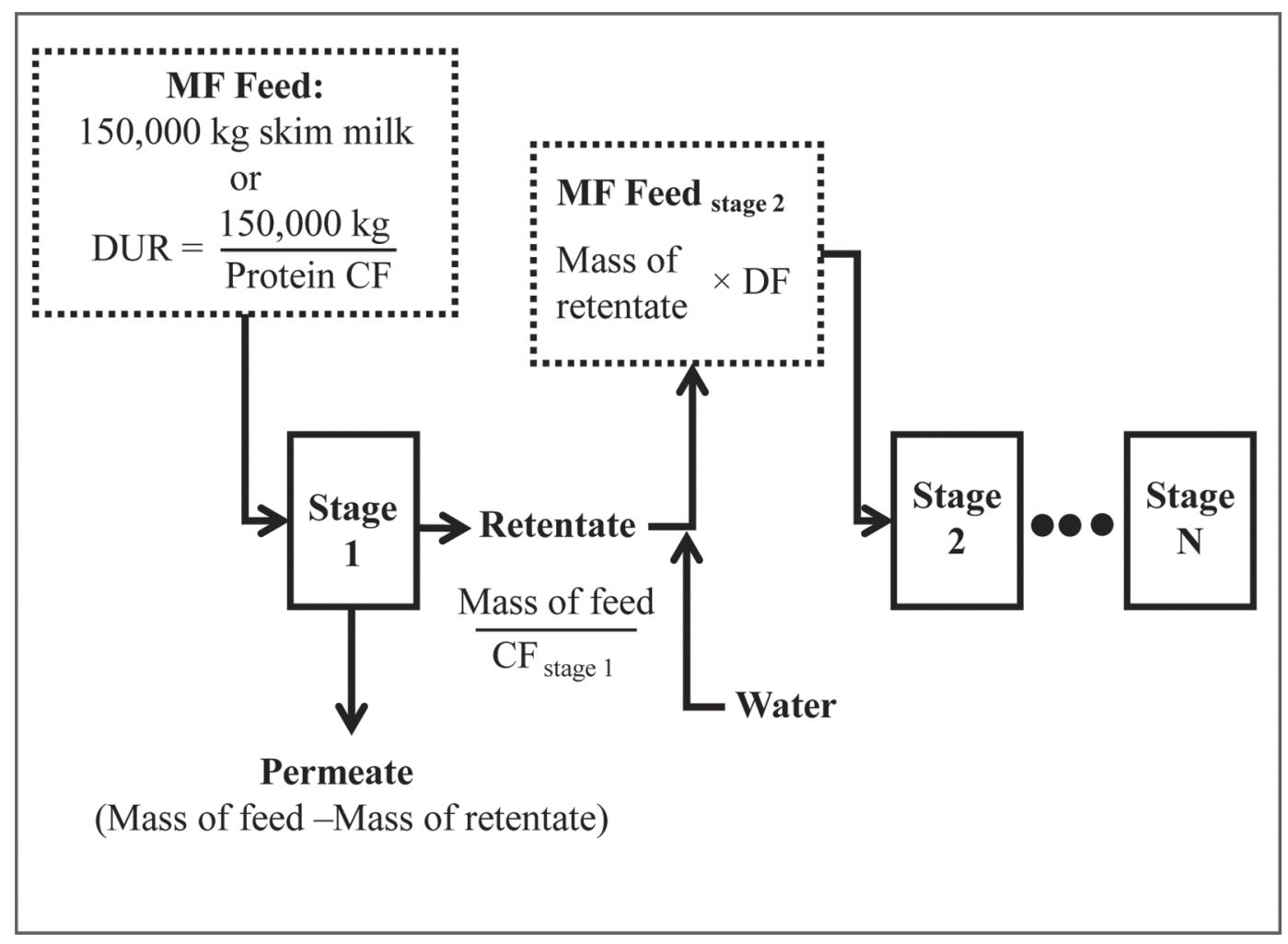

Figure 1. Mass-balance basis of the theoretical model developed for the production of a micellar CN concentrate by microfiltration (MF). The initial feed was either skim milk (SM) or diluted UF retentate (DUR). The mass of retentate, permeate, and MF feed for the subsequent stage was determined by the concentration factor $(\mathrm{CF})$ and diafiltration factor (DF). 
that the MPC had a protein concentration of $12 \%$. The MPC would have to be diluted before MF to produce the MF feed: a diluted UF retentate (DUR); however, it did not have to necessarily be diluted to the protein concentration in the original SM before MF. In this work it was assumed that UF would remove $76 \%$ of the lactose, NPN, and soluble ash (where the soluble ash was assumed to be one-third of the ash in SM) from SM and would have the composition shown in Table 2. A $76 \%$ reduction in lactose was chosen, because an additional $95 \%$ removal of lactose from the UF SM (MPC) would result in a $98.8 \%$ lactose removal compared with SM, which was the target lactose removal for the MCC. In the model it was assumed that the rejection characteristics for lactose and SP by the MF membranes were the same, so the required $95 \%$ reduction in SP would also reduce the lactose content by $95 \%$.

UF SM Protein Concentration Factor. If the MF feed was a DUR, the protein concentration of the DUR feeding the MF process was another factor that could affect the required MF membrane area. A DUR protein CF was added to the model. The protein concentration in the MF feed was equal to the DUR protein $\mathrm{CF}$ multiplied by the protein concentration of SM $(3.2 \%)$. With a DUR protein CF of one, the MF feed would have the same protein concentration as SM, whereas with a DUR protein CF of 2 , the MF feed would have twice the protein concentration of SM. The concentration of lactose, NPN, and ash in the DUR was modified so that their concentration equaled the DUR protein CF times the DUR composition shown in Table 2. This kept the ratio of lactose, NPN, and ash to protein in the DUR constant. If the MF feed was DUR, the mass of MF feed was modified so that the total mass of protein feeding the process was constant. For example if the DUR protein CF was 2, the mass of MF feed would be $75,000 \mathrm{~kg}$ as opposed to $150,000 \mathrm{~kg}$. In this way the mass of MCC produced was constant and did not depend on the DUR protein CF.

Number of MF Stages. The model allowed the MF process to include from 2 to 5 stages. A stage was defined as a MF unit having the same MF feed and producing retentate of the same composition. Water dilution of the retentates took place between stages, to produce the feed for the subsequent stage.

MF Flux. The flux that the MF process operates at would also affect the required membrane area. The flux would not have an effect on the amount of MF permeate that had to be removed but rather the time required to remove it. A default flux of $54 \mathrm{~kg} / \mathrm{m}^{2}$ per hour was chosen because previous research on the MF of SM had shown that a uniform transmembrane pressure MF system with $0.1-\mu \mathrm{m}$ ceramic membranes with 4-mm channel diameters could operate for extended periods of time at this flux when the feed was SM and the process operated at a $\mathrm{CF}$ of $3 \times$ (Zulewska et al., 2009). The effect of increasing the flux up to $80 \mathrm{~kg} /$ $\mathrm{m}^{2}$ per hour on required MF membrane area was also calculated.

\section{Minimization of MF Permeate}

Excel 2007 Solver (Microsoft) was used to minimize the total mass of MF permeate produced by the MF process in the theoretical model. The total mass of permeate was equal to the sum of the mass of permeate produced in each stage. The mass of MF permeate was minimized by changing the $\mathrm{CF}$ and $\mathrm{DF}$ for each stage. If the MF feed was DUR, the DUR protein CF could be changed as well to minimize the mass of MF permeate.

Model Constraints. In minimizing the mass of permeate in the theoretical model, 4 constraints were imposed as shown in Table 3. The first constraint limited the concentration of protein in the recirculation loop in all but the last stage to $\leq 8.6 \%$. Previous research had indicated that a uniform transmembrane pressure system with ceramic $0.1-\mu \mathrm{m}$ membranes could operate at a flux of $54 \mathrm{~kg} / \mathrm{m}^{2}$ per hour with retentate protein concentrations in the 8.6 to $9 \%$ range (Zulewska et al., 2009). A maximum protein concentration of $8.6 \%$ was chosen as opposed to $9 \%$ in all but the final stage, so that the process would have a built in safety factor. It is acknowledged that the retentate protein concentration would likely vary, and having a slightly lower maximum retentate protein concentration in all but the final stage would allow the MF process to operate consistently despite this variation. Constraints 2, 3, and 4 shown in Table 3 ensure that the final retentate composition achieved the target MCC composition as shown in Table 1.

The total number of stages in the MF process could be $2,3,4$, or 5 . As shown in Table 3 , there was one less $\mathrm{DF}$ variable than $\mathrm{CF}$ variable, because the final $\mathrm{MF}$ retentate was the MCC and not diluted with water. Additionally, all the $\mathrm{CF}$ and DF were constrained to be greater than or equal to one to model an actual MF process where MF permeate would be removed in each stage and diafiltration water would be added between stages.

Converting Mass of Permeate to Required Membrane Area. Solving the model subjected to the constraints shown in Table 3 provided the CF and DF that produced the minimal mass of MF permeate for the entire MF process. Up until this point flux did not play a role in the model. The mass of permeate was converted to membrane area by specifying a mass of 
Table 3. Objective function and constraints used to minimize the amount of microfiltration (MF) permeate produced by a MF process producing a micellar CN concentrate $(\mathrm{MCC})^{1}$

\begin{tabular}{ll}
\hline Item & Definition of variables \\
\hline Objective function & \\
$\sum_{\text {Stage } n}$ Mass of Permeate $_{i}$ & $i=$ stages 1 to $N$ \\
Minimize Stage $i$ & $i=$ stages 1 to $N-1$ \\
Subject to & \\
(1) Retentate protein ${ }_{i} \leq 8.6 \%$ & \\
(2) Retentate protein & \\
(3) MCC serum protein concentration $\leq 0.098 \%$ & \\
(4) MCC lactose concentration $\leq 0.2 \%$ & \\
Variables & \\
DUR protein concentration factor & \\
Concentration factor ${ }^{2}$ & \\
Diafiltration factor ${ }_{k}{ }^{2}$ & $k=$ stages 1 to $N$ \\
\hline
\end{tabular}

${ }^{1}$ The MF feed could be skim milk or diluted UF retentate (DUR). $N=2,3,4$, or 5 stages.

${ }^{2}$ Concentration factor $i$ and diafiltration factor $_{k} \geq 1$.

SM to be processed in a given period of time at a specific flux. For this work it was assumed that $150,000 \mathrm{~kg}$ of SM (or the protein equivalent) was to be processed in 18 h. Finally, unless otherwise specified a flux of 54 $\mathrm{kg} / \mathrm{m}^{2}$ per hour was used to calculate the required MF membrane area. The equation used to convert mass of permeate to membrane area is shown in Equation 2 below:

$$
\text { Membrane area }\left(\mathrm{m}^{2}\right)=\frac{\text { Mass of permeate }(\mathrm{kg})}{\operatorname{Flux}\left(\frac{\mathrm{kg}}{\mathrm{m}^{2} \mathrm{~h}}\right) \times 18 \mathrm{~h}} .
$$

\section{RESULTS AND DISCUSSION}

\section{Binding Constraints}

One of our goals was to determine the minimum amount of membrane area needed to process a give mass of milk in a given time. When the mass of MF permeate produced by the MF process was minimized using the model described above, some of the constraints (shown in Table 3) were always binding (the value of the constraint at the optimal solution was equal to the right-hand side of the constraint). The protein concentration of the retentate was always at the maximum-allowable concentration $(8.6 \%$ in all but the final stage) in the optimal solution. If the retentate was only concentrated to $7 \%$ protein in a stage when it could go to $8.6 \%$ protein, then that stage would remove less SP and lactose (less permeate is being removed in that stage) than it could have. The additional mass of SP and lactose would have to be removed in later stages. Because there is diafiltration between stages, to remove this mass of SP and lactose in the next stage would require a removal of an even larger mass of permeate and require more membrane surface area.

When the MF feed was SM, the MCC SP constraint (constraint 3 in Table 3) was nonbinding. The target MCC composition required at least a $95 \%$ removal of SP and a $98.8 \%$ removal of lactose. When the feed was SM, to achieve $98.8 \%$ lactose removal, $98.8 \%$ of the SP was removed as well. In contrast when the MF feed was DUR, by design a $95 \%$ removal of SP and lactose would produce an MCC meeting the target specification, and both the SP and lactose constraints for the MCC were binding (although redundant).

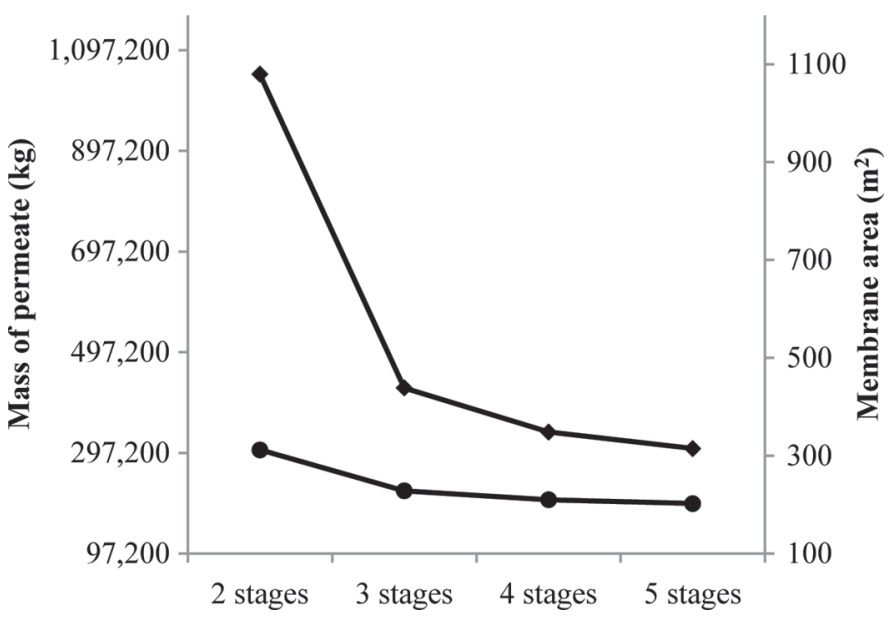

Figure 2. Theoretical microfiltration (MF) membrane area and mass of MF permeate produced in a MF process producing a micellar $\mathrm{CN}$ concentrate from either $(\checkmark)$ skim milk or $(\bullet)$ diluted UF retentate (DUR) (with a $76 \%$ reduction in lactose) for 2,3 , 4 , or 5 stages. The protein concentration of the DUR feeding the MF process was the same as skim milk. 
Table 4. Skim milk as the microfiltration (MF)-process feed: Composition and mass of MF feeds, retentates, and permeates for each stage of a 2- or 3-stage process, with concentration factors $(\mathrm{CF})$

\begin{tabular}{|c|c|c|c|c|c|}
\hline \multirow[b]{2}{*}{ Item } & \multicolumn{2}{|c|}{ 2-Stage process } & \multicolumn{3}{|c|}{ 3-Stage process } \\
\hline & Stage 1 & Stage 2 & Stage 1 & Stage 2 & Stage 3 \\
\hline \multicolumn{6}{|l|}{ Feed_skim milk } \\
\hline Diafiltration water $(\mathrm{kg})$ & & 943,133 & & 160,115 & 159,896 \\
\hline Mass (kg) & 150,000 & 991,940 & 150,000 & 208,922 & 206,270 \\
\hline True protein $(\%)$ & 3.20 & 0.42 & 3.20 & 2.01 & 1.93 \\
\hline $\mathrm{CN}(\%)$ & 2.62 & 0.40 & 2.62 & 1.88 & 1.91 \\
\hline Serum protein $(\%)$ & 0.58 & 0.03 & 0.58 & 0.13 & 0.03 \\
\hline Lactose $(\%)$ & 4.85 & 0.22 & 4.85 & 1.06 & 0.22 \\
\hline $\mathrm{NPN}(\%)$ & 0.19 & 0.01 & 0.19 & 0.04 & 0.01 \\
\hline Ash $(\%)$ & 0.73 & 0.08 & 0.73 & 0.40 & 0.36 \\
\hline \multicolumn{6}{|l|}{ Retentate } \\
\hline MF CF & 3.07 & 22.63 & 3.07 & 4.51 & 4.71 \\
\hline Mass (kg) & 48,807 & 43,833 & 48,807 & 46,374 & 43,833 \\
\hline True protein $(\%)$ & 8.60 & 9.00 & 8.60 & 8.60 & 9.00 \\
\hline $\mathrm{CN}(\%)$ & 8.06 & 8.98 & 8.06 & 8.48 & 8.98 \\
\hline Serum protein (\%) & 0.54 & 0.02 & 0.54 & 0.12 & 0.02 \\
\hline Lactose $(\%)$ & 4.53 & 0.20 & 4.53 & 0.97 & 0.20 \\
\hline NPN (\%) & 0.18 & 0.01 & 0.18 & 0.04 & 0.01 \\
\hline Ash (\%) & 1.72 & 1.67 & 1.72 & 1.62 & 1.67 \\
\hline \multicolumn{6}{|l|}{ Permeate } \\
\hline Mass $(\mathrm{kg})$ & 101,193 & 948,107 & 101,193 & 162,547 & 162,438 \\
\hline True protein (\%) & 0.60 & 0.03 & 0.60 & 0.13 & 0.03 \\
\hline $\mathrm{CN}(\%)$ & 0.00 & 0.00 & 0.00 & 0.00 & 0.00 \\
\hline Serum protein (\%) & 0.60 & 0.03 & 0.60 & 0.13 & 0.03 \\
\hline Lactose $(\%)$ & 5.01 & 0.22 & 5.01 & 1.08 & 0.22 \\
\hline NPN $(\%)$ & 0.20 & 0.01 & 0.20 & 0.04 & 0.01 \\
\hline $\operatorname{Ash}(\%)$ & 0.25 & 0.01 & 0.25 & 0.05 & 0.01 \\
\hline
\end{tabular}

Table 5. Skim milk as the microfiltration (MF)-process feed: Composition and mass of MF feeds, retentates, and permeates for each stage of a 4- or 5-stage MF process, with concentration factors $(\mathrm{CF})$

\begin{tabular}{|c|c|c|c|c|c|c|c|c|c|}
\hline Item & Stage 1 & Stage 2 & Stage 3 & Stage 4 & Stage 1 & Stage 2 & Stage 3 & Stage 4 & Stage 5 \\
\hline Diafiltration water $(\mathrm{kg})$ & & 77,558 & 77,565 & 77,279 & & 49,966 & 50,074 & 49,830 & 49,851 \\
\hline Mass $(\mathrm{kg})$ & 150,000 & 126,365 & 124,374 & 123,395 & 150,000 & 98,773 & 97,203 & 96,202 & 95,882 \\
\hline True protein (\%) & 3.20 & 3.32 & 3.24 & 3.21 & 3.20 & 4.25 & 4.17 & 4.15 & 4.13 \\
\hline $\mathrm{CN}(\%)$ & 2.62 & 3.11 & 3.16 & 3.19 & 2.62 & 3.98 & 4.05 & 4.09 & 4.10 \\
\hline NPN (\%) & 0.19 & 0.07 & 0.02 & 0.01 & 0.19 & 0.09 & 0.04 & 0.02 & 0.01 \\
\hline Ash $(\%)$ & 0.73 & 0.66 & 0.62 & 0.60 & 0.73 & 0.85 & 0.80 & 0.78 & 0.77 \\
\hline \multicolumn{10}{|l|}{ Retentate } \\
\hline $\mathrm{MF}$ CF & 3.07 & 2.70 & 2.70 & 2.82 & 3.07 & 2.10 & 2.10 & 2.09 & 2.19 \\
\hline Mass $(\mathrm{kg})$ & 48,807 & 46,809 & 46,117 & 43,832 & 48,807 & 47,129 & 46,372 & 46,031 & 43,832 \\
\hline True protein (\%) & 8.60 & 8.60 & 8.60 & 9.00 & 8.60 & 8.60 & 8.60 & 8.60 & 9.00 \\
\hline $\mathrm{CN}(\%)$ & 8.06 & 8.41 & 8.53 & 8.98 & 8.06 & 8.35 & 8.48 & 8.55 & 8.98 \\
\hline \multicolumn{10}{|l|}{ Permeate } \\
\hline Mass (kg) & 101,193 & 79,557 & 78,257 & 79,563 & 101,193 & 51,643 & 50,832 & 50,171 & 52,050 \\
\hline True protein $(\%)$ & 0.60 & 0.22 & 0.08 & 0.03 & 0.60 & 0.28 & 0.13 & 0.06 & 0.03 \\
\hline $\mathrm{CN}(\%)$ & 0.00 & 0.00 & 0.00 & 0.00 & 0.00 & 0.00 & 0.00 & 0.00 & 0.00 \\
\hline Serum protein (\%) & 0.60 & 0.22 & 0.08 & 0.03 & 0.60 & 0.28 & 0.13 & 0.06 & 0.03 \\
\hline Lactose $(\%)$ & 5.01 & 1.82 & 0.64 & 0.22 & 5.01 & 2.35 & 1.08 & 0.49 & 0.22 \\
\hline NPN (\%) & 0.20 & 0.07 & 0.03 & 0.01 & 0.20 & 0.09 & 0.04 & 0.02 & 0.01 \\
\hline Ash $(\%)$ & 0.25 & 0.09 & 0.03 & 0.01 & 0.25 & 0.12 & 0.05 & 0.02 & 0.01 \\
\hline
\end{tabular}


Table 6. Diluted UF retentate (DUR) at the protein concentration of skim milk as the microfiltration (MF)-process feed: Composition and mass of MF feeds, retentates, and permeates for each stage of a 2- or 3-stage MF process, with concentration factors $(\mathrm{CF})$

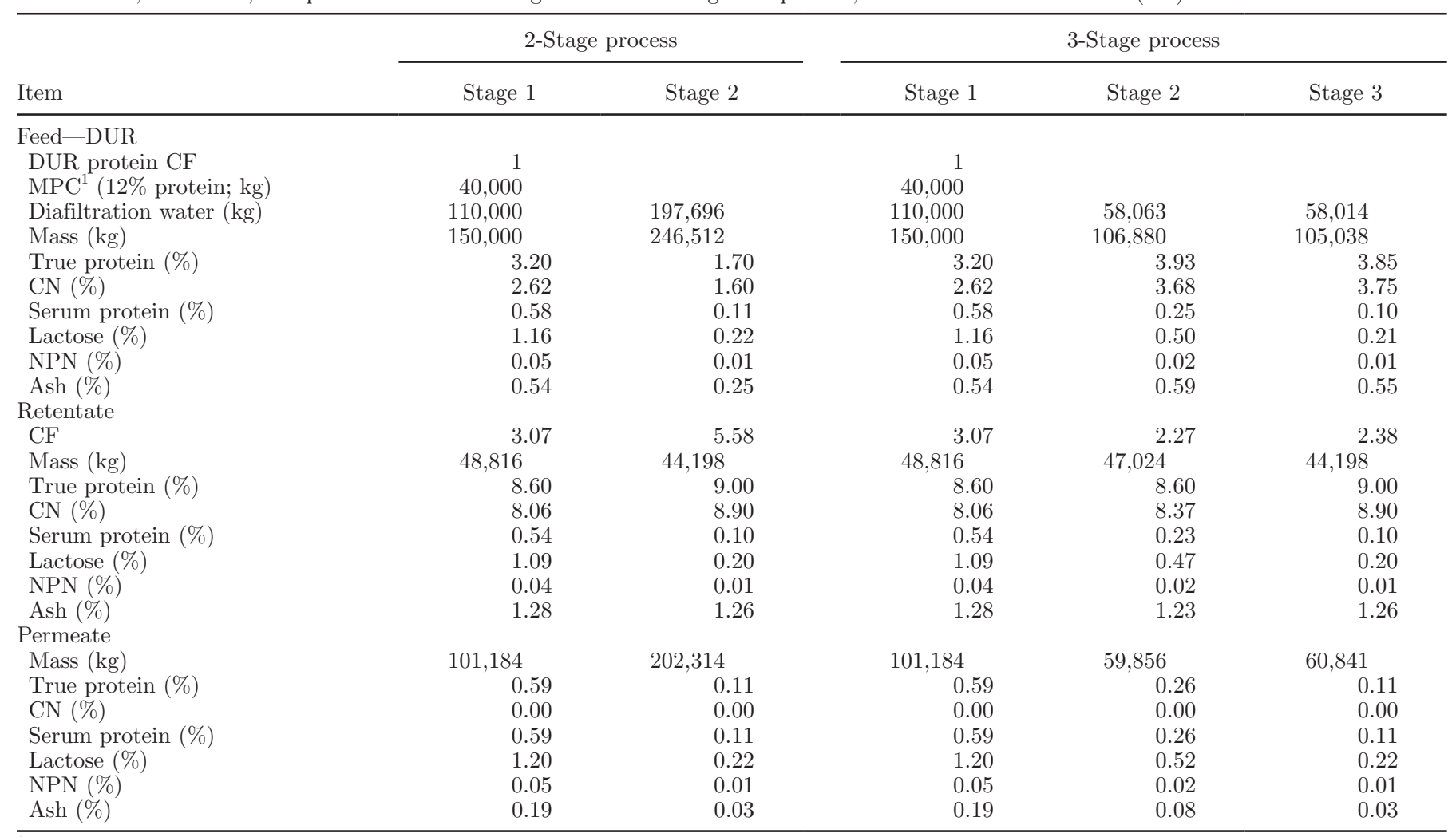

${ }^{1} \mathrm{MPC}=$ milk protein concentrate.

\section{UF of SM}

The MF membrane area required (and mass of MF permeate removed) to produce an MCC from SM compared with DUR is shown in Figure 2, for 2, 3, 4, or 5 stages. In Figure 2 the DUR protein concentration was the same as SM (3.2\%). The feed, retentate, and permeate masses and compositions when the MF feed was SM or DUR at the protein concentration of SM are shown in Tables 4, 5, 6, and 7. For a 2-stage MF process, feeding the MF process with a DUR reduced the required MF membrane area (Figure 2) by $71 \%$ (from 1,080 to $312 \mathrm{~m}^{2}$ ), and for a 5-stage process, the required MF membrane area (Figure 2) was reduced by $36 \%$ (from 315 to $202 \mathrm{~m}^{2}$ ).

Feeding the MF process with DUR reduced the required MF membrane area, because the target MCC required a larger reduction in lactose than $\mathrm{SP}$ as shown in Table 1. Ultrafiltration reduced the amount of lactose in the MF feed to a level where a MF process to remove $95 \%$ of the SP from the feed would result in an MCC that met the lactose-removal target specification. As shown in Tables 4, 5, 6, and 7 the MCC produced starting from SM has a lower concentration of SP than when the starting material was DUR. The use of an MPC with greater than $76 \%$ of the lactose removed would not further reduce the required MF membrane area because the MF process would still be required to remove $95 \%$ of the $\mathrm{SP}$.

A UF system to remove lactose from SM before MF would be an additional cost. However, polymeric spiralwound UF systems are less expensive than ceramic MF systems (Cheryan, 1998). The savings achieved by reducing the required MF membrane area could offset the cost of the UF system if no UF system was already available in the factory.

The DUR MF feed would be produced by diluting a fresh liquid MPC, and the protein concentration of this DUR was an additional variable in the model. The DUR protein concentration had an effect on the required MF membrane area and mass of permeate produced for a 2-, 3-, 4-, or 5-stage MF process as shown in Figure 3. The DUR protein $\mathrm{CF}$ that minimized the required membrane area was $0.77,1.20,1.49$, and 1.69 for $2,3,4$, or 5 stages, respectively, which corresponds to MF feed protein concentrations of $2.47,3.85,4.77$, and $5.41 \%$, respectively, as shown in Tables 8 and 9. For a 5-stage MF process, increasing the DUR protein concentration 
from 3.2 to $5.41 \%$ reduced the required MF membrane area from 202 to $182 \mathrm{~m}^{2}$.

As the protein concentration in the MF feed (DUR) was decreased, the required MF membrane area began to converge, regardless of the number of stages as shown in Figure 3. This is because it was possible to dilute the DUR so that the concentration of SP was less than $0.098 \%$; at this point no diafiltration would be required and the feed would only have to be concentrated to $9 \%$ protein, making the number of MF stages irrelevant but requiring more membrane surface area.

\section{Number of MF Stages}

As the number of MF stages was increased from 2 to 5 , the required membrane area decreased by $39 \%$ from 297 to $182 \mathrm{~m}^{2}$, as shown in Figure 4. In Figure 4 it was assumed the MF feed was DUR and the DUR protein concentration was at the optimal value for each number of stages $(2.47,3.85,4.77$, and $5.4 \%$ protein for a $2-, 3-$, 4 -, or 5-stage MF process, respectively). Increasing the number of stages from 2 to 3 resulted in a $24 \%$ decrease in required MF membrane area (and in the mass of MF permeate removed), whereas increasing the number of stages from 4 to 5 only resulted in a $7 \%$ decrease in required membrane area.

Additional advantages of increasing the number of MF stages include the reduction in diafiltration water that was required by the process as shown in Tables 8 and 9 and the decreased mass of MF permeate as shown in Figure 4. Providing the required diafiltration water will have some cost associated with it. Reducing the mass of MF permeate also increased the average concentration of SP in the permeate (Tables 8 and 9), which would reduce the concentration required to produce SP concentrates.

Increasing the number of stages beyond 5 would continue to decrease the required membrane area; however, the additional reduction in membrane area for each additional stage would also continue to decrease. At some point, the costs associated with the addition of an extra stage (i.e., pumps, controls, and piping) would be larger than the savings in membrane area realized for the addition of that stage. Additionally, membrane area is not a continuous variable, and there will be a

Table 7. Diluted UF retentate (DUR) at the protein concentration of skim milk as the microfiltration (MF)-process feed: Composition and mass of MF feeds, retentates, and permeates for each stage of a 4- or 5-stage MF process, with concentration factors $(\mathrm{CF})$

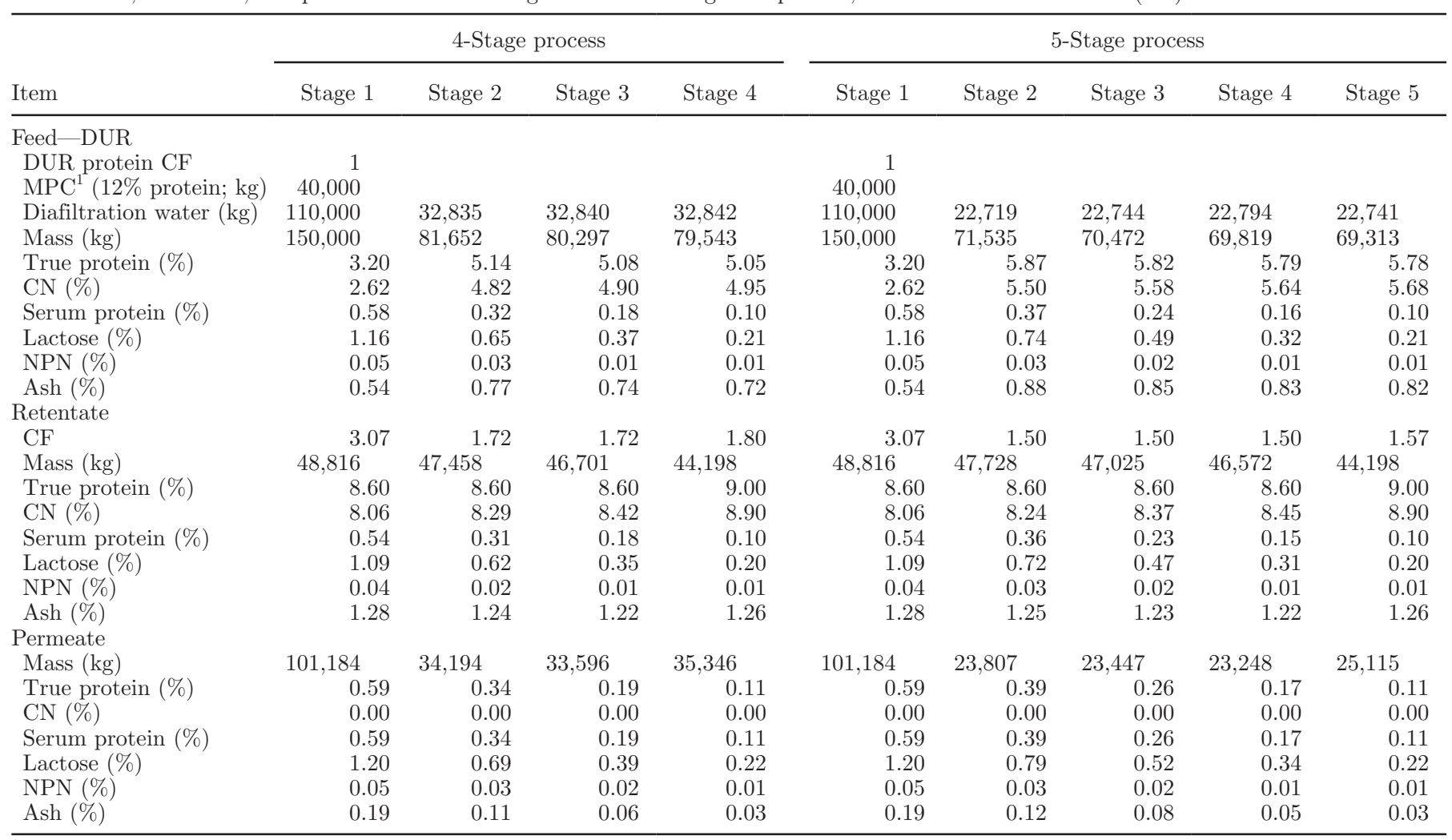

${ }^{1} \mathrm{MPC}=$ milk protein concentrate. 


\section{MF feed protein concentration (\%)}

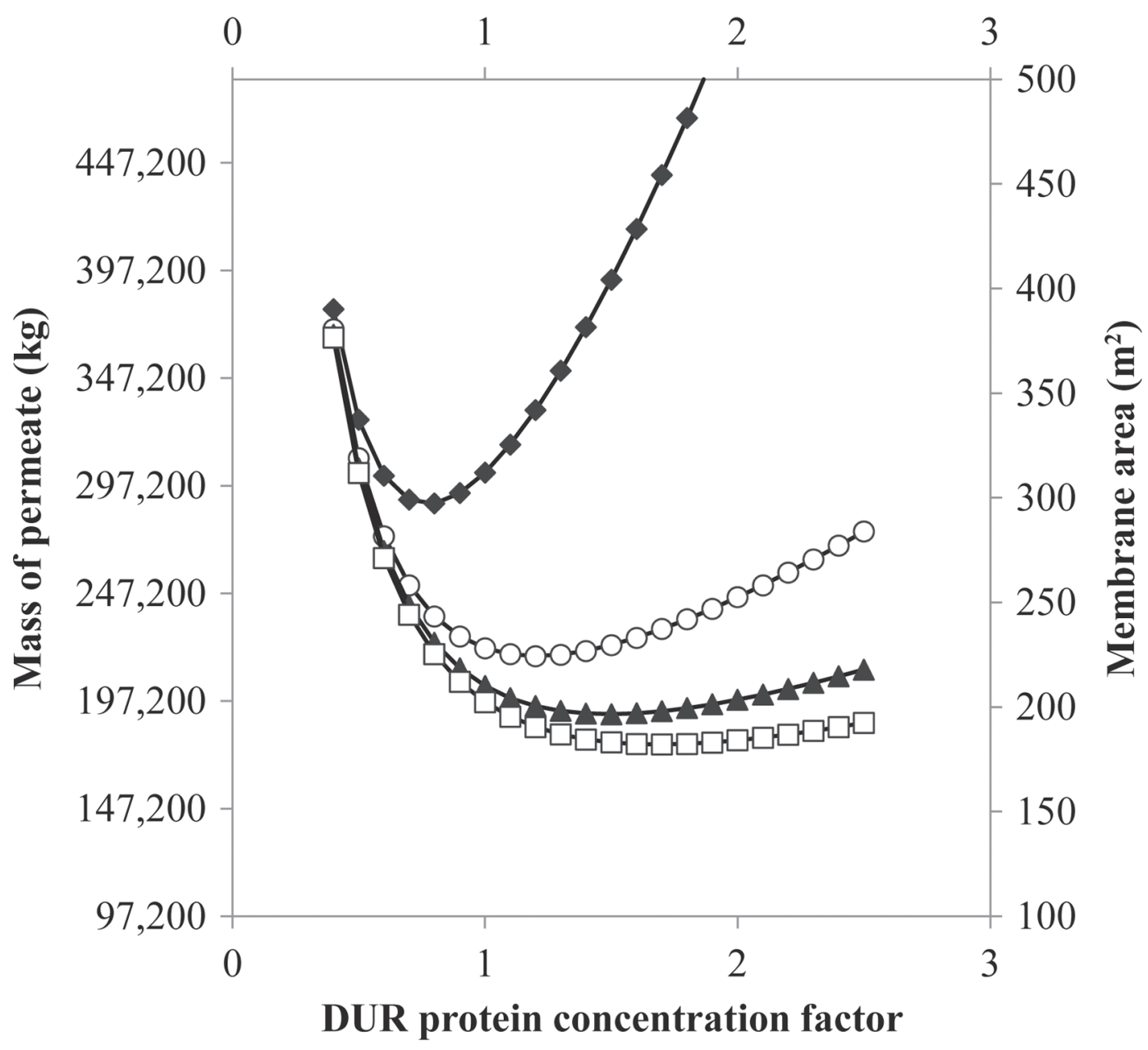

Figure 3. Theoretical microfiltration (MF) membrane area required and mass of permeate produced as a function of the diluted UF retentate (DUR) concentration factor of the MF feed. The number of MF stages used for the micellar CN concentrate production were $2(\checkmark), 3$ ( $\mathrm{C}), 4$ $(\boldsymbol{\Lambda})$, or $5(\square)$. The starting MF feed was DUR.

finite membrane area that can be accommodated in each module in a stage.

\section{MF Flux}

The effect of flux on the required MF membrane area is shown in Figure 5; increasing the flux from 50 to $60 \mathrm{~kg} / \mathrm{m}^{2}$ per hour decreased the required membrane area by $17 \%$ regardless of the number of MF stages (from 197 to $164 \mathrm{~m}^{2}$ for a 5 -stage MF process). It was assumed that the MF feed was DUR diluted to the optimal protein concentration. The flux did not affect the amount of MF permeate that had to be removed (or diafiltration water required), but as shown in Equation 1 and Figure 5, it did affect the MF membrane area required. In this work it was assumed that the
MF process could operate at a flux of $50,60,70$, or 80 $\mathrm{kg} / \mathrm{m}^{2}$ per hour for extended periods of time without membrane fouling that would lead to a reduction in flux or changes in the transmission of SP or lactose through the membrane. Factors, particularly properties of the feed material that may influence flux, could have a large effect on the amount of membrane area required in an MF system.

Realistically, given a retentate protein concentration and membrane system, there will be a limiting flux that the MF system will not be able to operate above. Several factors could affect the limiting flux, including protein concentration (Vadi and Rizvi, 2001), temperature, and shear stress at the surface of the membrane (Samuelsson et al., 1997). Further research will be required to determine the limiting flux at different MF recirculation-loop protein concentrations. 
Table 8. Diluted UF retentate (DUR) at the protein concentration that minimized the microfiltration (MF) membrane area as the MF-process feed: Composition and mass of MF feeds, retentates, and permeates for each stage of a 2- or 3-stage MF process, with concentration factors (CF)

\begin{tabular}{|c|c|c|c|c|c|}
\hline \multirow[b]{2}{*}{ Item } & \multicolumn{2}{|c|}{ 2-Stage process } & \multicolumn{3}{|c|}{ 3-Stage process } \\
\hline & Stage 1 & Stage 2 & Stage 1 & Stage 2 & Stage 3 \\
\hline DUR protein $\mathrm{CF}$ & 0.77 & & 1.20 & & \\
\hline $\operatorname{MPC}^{1}(12 \%$ protein; $\mathrm{kg})$ & 40,000 & & 40,000 & & \\
\hline Diafiltration water $(\mathrm{kg})$ & 154,446 & 138,658 & 84,674 & 68,888 & 68,847 \\
\hline Mass (kg) & 194,446 & 186,717 & 124,674 & 118,409 & 116,010 \\
\hline Serum protein $(\%)$ & 0.45 & 0.11 & 0.69 & 0.27 & 0.10 \\
\hline Lactose $(\%)$ & 0.90 & 0.21 & 1.40 & 0.55 & 0.21 \\
\hline NPN $(\%)$ & 0.04 & 0.01 & 0.05 & 0.02 & 0.01 \\
\hline Ash $(\%)$ & 0.45 & 0.36 & 0.65 & 0.55 & 0.50 \\
\hline \multicolumn{6}{|l|}{ Retentate } \\
\hline $\mathrm{CF}$ & 4.05 & 4.22 & 2.52 & 2.51 & 2.62 \\
\hline Mass (kg) & 48,059 & 44,198 & 49,521 & 47,163 & 44,198 \\
\hline Ash $(\%)$ & 1.27 & 1.27 & 1.30 & 1.23 & 1.26 \\
\hline \multicolumn{6}{|l|}{ Permeate } \\
\hline Mass (kg) & 146,387 & 142,519 & 75,152 & 71,246 & 71,812 \\
\hline True protein $(\%)$ & 0.46 & 0.11 & 0.72 & 0.28 & 0.11 \\
\hline $\mathrm{CN}(\%)$ & 0.00 & 0.00 & 0.00 & 0.00 & 0.00 \\
\hline Serum protein $(\%)$ & 0.46 & 0.11 & 0.72 & 0.28 & 0.11 \\
\hline Lactose (\%) & 0.92 & 0.22 & 1.45 & 0.57 & 0.22 \\
\hline $\mathrm{NPN}(\%)$ & 0.04 & 0.01 & 0.06 & 0.02 & 0.01 \\
\hline Ash $(\%)$ & 0.15 & 0.04 & 0.23 & 0.09 & 0.03 \\
\hline
\end{tabular}

${ }^{1} \mathrm{MPC}=$ milk protein concentrate.

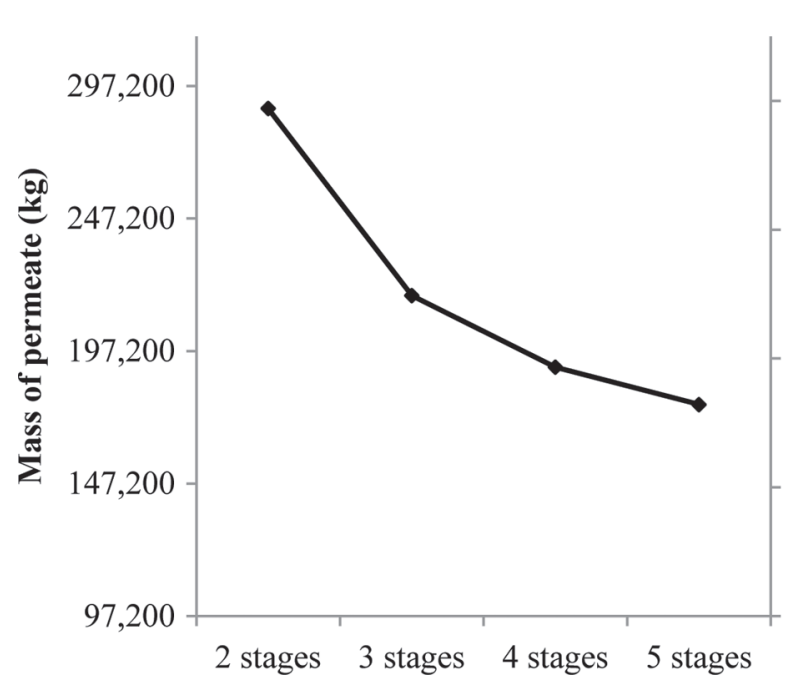

Figure 4. Theoretical microfiltration (MF) membrane area and mass of permeate produced in a 2-, 3-, 4-, or 5-stage MF process producing a micellar CN concentrate. The MF feed was diluted UF retentate (DUR) with a protein concentration of $2.47,3.85,4.77$, and $5.41 \%$ for a 2-, 3-, 4-, or 5-stage MF process, respectively.

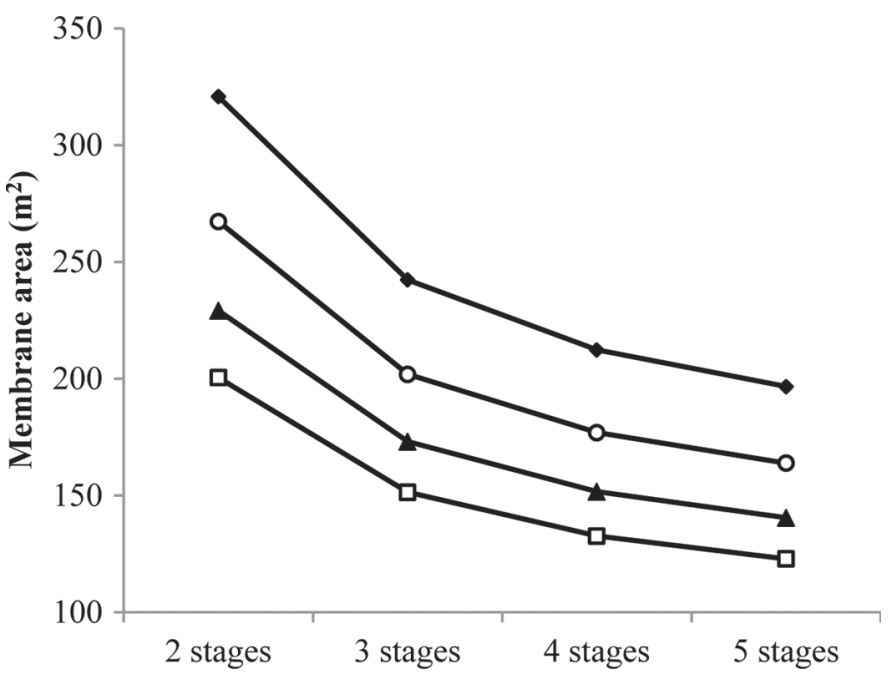

Figure 5. Theoretical microfiltration (MF) membrane area required for a process containing $2,3,4$, or $5 \mathrm{MF}$ stages, operating at a flux of $(\checkmark) 50,(\bigcirc) 60,(\boldsymbol{\Delta}) 70$, or $(\square) 80 \mathrm{~kg} / \mathrm{m}^{2}$ per hour. The MF feed was diluted UF retentate (DUR) with a protein concentration of $2.47,3.85,4.77$, and $5.41 \%$ for a $2-, 3-, 4-$, or 5 -stage MF process, respectively. 
Table 9. Diluted UF retentate (DUR) at the protein concentration that minimized the microfiltration (MF) membrane area as the MF-process feed: Composition and mass of MF feeds, retentates, and permeates for each stage of a 4- or 5-stage MF process, with concentration factors (CF)

\begin{tabular}{|c|c|c|c|c|c|c|c|c|c|}
\hline \multirow[b]{2}{*}{ Item } & \multicolumn{4}{|c|}{ 4-Stage process } & \multicolumn{5}{|c|}{ 5-Stage process } \\
\hline & Stage 1 & Stage 2 & Stage 3 & Stage 4 & Stage 1 & Stage 2 & Stage 3 & Stage 4 & Stage 5 \\
\hline DUR protein $\mathrm{CF}$ & 1.49 & & & & 1.69 & & & & \\
\hline MPC $(12 \%$ protein; $\mathrm{kg})$ & 40,000 & & & & 40,000 & & & & \\
\hline Diafiltration water $(\mathrm{kg})$ & 60,715 & 44,902 & 44,898 & 44,896 & 48,757 & 33,113 & 33,124 & 33,162 & 33,167 \\
\hline Mass (kg) & 100,715 & 95,472 & 92,957 & 91,752 & 88,757 & 84,460 & 81,979 & 80,635 & 79,872 \\
\hline Serum protein $(\%)$ & 0.86 & 0.43 & 0.21 & 0.10 & 0.98 & 0.57 & 0.33 & 0.18 & 0.10 \\
\hline Lactose $(\%)$ & 1.73 & 0.88 & 0.43 & 0.21 & 1.97 & 1.15 & 0.66 & 0.37 & 0.21 \\
\hline NPN $(\%)$ & 0.07 & 0.03 & 0.02 & 0.01 & 0.08 & 0.04 & 0.03 & 0.01 & 0.01 \\
\hline $\operatorname{Ash}(\%)$ & 0.81 & 0.71 & 0.65 & 0.63 & 0.92 & 0.82 & 0.77 & 0.73 & 0.71 \\
\hline \multicolumn{10}{|l|}{ Retentate } \\
\hline $\mathrm{CF}$ & 1.99 & 1.99 & 1.98 & 2.08 & 1.73 & 1.73 & 1.73 & 1.73 & 1.81 \\
\hline Mass $(\mathrm{kg})$ & 50,570 & 48,058 & 46,856 & 44,198 & 51,347 & 48,855 & 47,473 & 46,705 & 44,198 \\
\hline Ash $(\%)$ & 1.33 & 1.26 & 1.22 & 1.26 & 1.35 & 1.29 & 1.24 & 1.22 & 1.26 \\
\hline \multicolumn{10}{|l|}{ Permeate } \\
\hline Mass $(\mathrm{kg})$ & 50,145 & 47,414 & 46,101 & 47,554 & 37,411 & 35,605 & 34,507 & 33,930 & 35,675 \\
\hline True protein $(\%)$ & 0.90 & 0.46 & 0.22 & 0.11 & 1.03 & 0.60 & 0.34 & 0.19 & 0.11 \\
\hline $\mathrm{CN}(\%)$ & 0.00 & 0.00 & 0.00 & 0.00 & 0.00 & 0.00 & 0.00 & 0.00 & 0.00 \\
\hline Serum protein (\%) & 0.90 & 0.46 & 0.22 & 0.11 & 1.03 & 0.60 & 0.34 & 0.19 & 0.11 \\
\hline Lactose (\%) & 1.81 & 0.92 & 0.45 & 0.22 & 2.07 & 1.21 & 0.70 & 0.39 & 0.22 \\
\hline NPN $(\%)$ & 0.07 & 0.04 & 0.02 & 0.01 & 0.08 & 0.05 & 0.03 & 0.02 & 0.01 \\
\hline Ash $(\%)$ & 0.28 & 0.14 & 0.07 & 0.03 & 0.32 & 0.19 & 0.11 & 0.06 & 0.03 \\
\hline
\end{tabular}

\section{Sensitivity Analysis}

The constraints used to minimize the required membrane area are shown in Table 3. Analysis was performed to determine how sensitive the mass of MF permeate removed and required MF membrane area was to changes in the various constraints. To perform the analysis a 5 -stage MF process was used where the MF feed was DUR diluted to the optimal protein concentration. A $\pm 5 \%$ change in each of the constraints was analyzed; the changes in each of the constraints are shown in Table 10.

Retentate Protein Concentration in Stages 1 to 4. As shown in Figure 6, increasing the allowable retentate protein concentration in stages 1 to 4 by $5 \%$, from 8.6 to $9.03 \%$, decreased the required MF mem- brane area from 182 to $174 \mathrm{~m}^{2}$; in contrast decreasing the allowable protein concentration from 8.6 to $8.17 \%$ increased the required MF membrane area from 182 to $191 \mathrm{~m}^{2}$. Although the theoretical model indicates that it would be desirable to increase the allowable retentate protein concentration, the effect of this decision on flux and SP transmission would have to be determined.

MCC Protein Concentration. Increasing the MCC protein concentration from 9.00 to $9.45 \%$ decreased the required MF membrane area from 182 to $180 \mathrm{~m}^{2}$, whereas decreasing the target MCC protein concentration from 9.00 to $8.55 \%$ increased the required membrane area from 182 to $184 \mathrm{~m}^{2}$ as shown in Figure 6 . Increasing the maximum protein concentration for 4 stages (stages 1 to 4 ) had a larger effect than increasing

Table 10. Sensitivity analysis, $5 \%$ change in the constraints on maximum retentate protein concentration in stages $1,2,3$, and 4 and final micellar CN concentrate (MCC) protein concentration ${ }^{1}$

\begin{tabular}{lcc}
\hline Constraint & $5 \%$ Increase & $5 \%$ Decrease \\
\hline Maximum retentate protein concentration in stages 1 to 4 & 9.03 & 8.17 \\
MCC protein concentration & 9.45 & 8.55 \\
\hline
\end{tabular}

${ }^{1}$ All values are given as percent on a weight basis. 


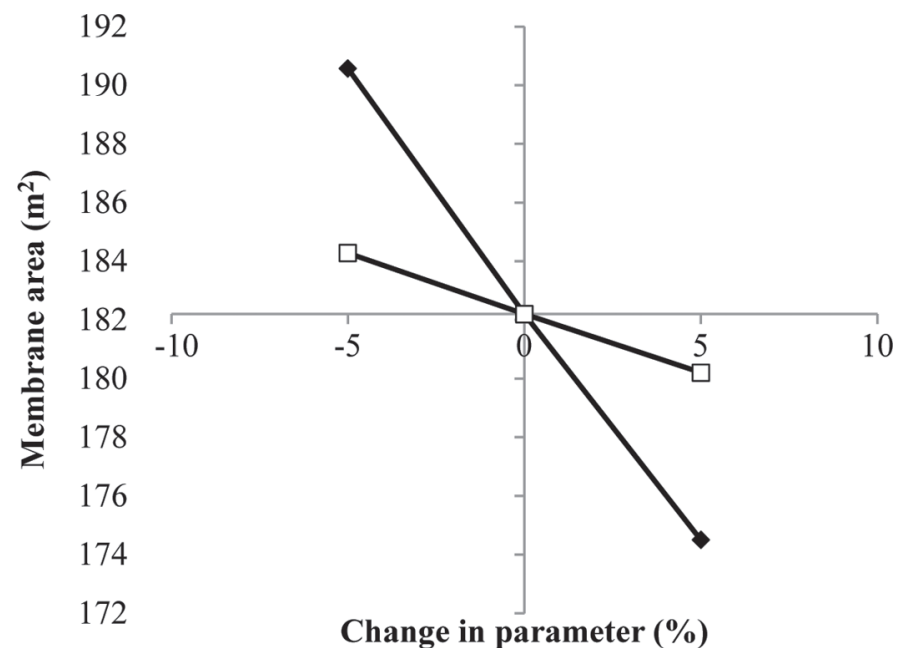

Figure 6. Percent change in required membrane area when the maximum-allowable $(\checkmark)$ retentate protein concentration was changed by $\pm 5 \%$; the target $(\square)$ micellar-CN-concentrate protein concentration was changed by $\pm 5 \%$.

the maximum protein concentration for the final stage (Figure 6).

\section{CONCLUSIONS}

The MF feed, number of stages, and flux were all factors that had an effect on the MF membrane area and should be taken into consideration when designing a MF system to produce a 95\% SP-reduced MCC. Feeding the MF process with DUR diluted with water to the protein concentration of SM, as opposed to SM, reduced the required membrane area by $36 \%$ for a 5 -stage process. When DUR was the MF feed, there was an optimal feed protein concentration that depended on the number of MF stages. The DUR protein concentration that minimized the required MF membrane area was $2.47,3.85,4.77$, and $5.41 \%$ for a $2-, 3-, 4-$, or 5 -stage MF process, respectively. For a 5 -stage process increasing the protein concentration of the feed from 3.2 to $5.4 \%$ decreased the required MF membrane area by $10 \%$. It was also found that as the number of stages increased from 2 to 5 , the required MF membrane area decreased by $39 \%$, when the MF feed was DUR at the optimal feed protein concentration. Finally, it was found that increasing the flux from 50 to $60 \mathrm{~kg} / \mathrm{m}^{2}$ per hour decreased the required MF membrane area by $17 \%$ when the MF feed was DUR at the optimal MF feed protein concentration. Overall, using water-diluted UF retentate of SM could over reduce the amount of ceramic MF membrane area required to make a $95 \%$ SP-reduced MCC.

\section{ACKNOWLEDGMENTS}

The authors thank the Northeast Dairy Foods Research Center (Ithaca, NY) and New York State Milk Production Board (Albany, NY) for partial funding of this research.

\section{REFERENCES}

Adams, M. C., and D. M. Barbano. 2013. Serum protein removal from skim milk with a 3 -stage $3 \times$ ceramic isoflux membrane process at $50^{\circ}$ C. J. Dairy Sci. 96:2020-2034.

Beckman, S. L., J. Zulewska, M. Newbold, and D. M. Barbano. 2010. Production efficiency of a micellar casein concentrate using spiralwound microfiltration membranes. J. Dairy Sci. 93:4506-4517.

Cheryan, M. 1998. Ultrafiltration and Microfiltration Handbook. Technomic Publ. Co. Inc., Lancaster, PA.

Fauquant, J., J.-L. Maubois, and A. Pierre. 1988. Microfiltration du lait sur membrane minerale. Technique Laitiere 1028:21-23.

Hurt, E., and D. M. Barbano. 2010. Processing factors that influence casein and serum protein separation by microfiltration. J. Dairy Sci. 93:4928-4941.

Hurt, E., J. Zuwleska, M. Newbold, and D. M. Barbano. 2010. Micellar casein concentrate productions with a $3 \times, 3$-stage uniform transmembrane pressure ceramic membrane process at $50^{\circ} \mathrm{C}$. J. Dairy Sci. 93:5588-5600.

Lawrence, N. D., S. E. Kentish, A. J. O'Conner, A. R. Barber, and G. W. Stevens. 2008. Microfiltration of skim milk using polymeric membranes for casein concentrate manufacture. Separ. Purif. Tech. 60:237-244.

Luck, P. J., B. Vardhanabhuti, T. H. Young, T. Laudon, D. M. Barbano, and E. A. Foegeding. 2013. Comparison of functional properties of $34 \%$ and $80 \%$ whey protein and milk serum protein concentrates. J. Dairy Sci. 96:5522-5531.

Samuelsson, G., I. H. Huisman, G. Tragardh, and M. Paulsson. 1997. Predicting limiting flux of skim milk in crossflow microfiltration. J. Membr. Sci. 129:277-281.

Vadi, P. K., and S. S. H. Rizvi. 2001. Experimental evaluation of a uniform transmembrane pressure crossflow microfiltration unit for the concentration of micellar casein from skim milk. J. Membr. Sci. 189:69-82.

Zulewska, J., and D. M. Barbano. 2014. The effect of linear velocity and flux on performance of ceramic graded permeability membranes when processing skim milk at $50^{\circ} \mathrm{C}$. J. Dairy Sci. 97:26192632.

Zulewska, J., M. Newbold, and D. M. Barbano. 2009. Efficiency of serum protein removal from skim milk with ceramic and polymeric membranes at $50^{\circ} \mathrm{C}$. J. Dairy Sci. 92:1361-1377. 